\title{
ANALISIS KESEHATAN FINANSIAL DAN KINERJA SOSIAL (STUDI KASUS BANK MUAMALAT INDONESIA DAN BANK SYARIAH MANDIRI)
}

\author{
Rivai Yusuf \\ Dosen Tetap Prodi Perbankan Syariah \\ Sekolah Tinggi Agama Islam Al Hidayah Bogor
}

\begin{abstract}
Abstrak
Dewasa ini, bank syariah diharapkan mampu menjadi solusi bagi permasalahan ekonomi global, baik itu bagi muslimin maupun non-muslim (prinsip: rahmatan lil alamin). Agar tercapai cita-cita yang diinginkan, maka perlu dilakukan program di semua lini masyarakat, mulai dari edukasi di bidang pendidikan, dunia usaha serta perbankan. Dengan mengedukasi masyarakat diharapkan sistem dan prinsip dasar ekonomi syariah dapat menjadi mindset dan landasan berekonomi yang kokoh. Selanjutnya perbankan syariah dituntut untuk lebih berperan aktif dalam hal sosialisasi kepada dunia usaha yang dilandasi dengan prinsip-prinsip syariah dan berinovasi terhadap kebutuhan masyarakat serta perkembangan zaman agar tujuannya yang mulia tersebut dapat terlaksana. Bank syariah dikembangkan sebagai lembaga bisnis keuangan yang melaksanakan kegiatan usahanya sejalan dengan prinsip-prinsip dasar dalam ekonomi Islam. Tujuan ekonomi Islam bagi bank syariah tidak hanya terfokus pada tujuan komersil yang tergambar pada pencapaian keuntungan maksimal semata, tetapi juga mempertimbangkan perannya dalam memberikan kesejahteraan secara luas bagi masyarakat. Kontribusi untuk turut serta dalam mewujudkan kesejahteraan masyarakat tersebut merupakan peran bank syariah dalam pelaksanaan fungsi sosialnya. Melalui fungsi sosial ini diharapkan akan memperlancar alokasi dan distribusi dana sosial yang dibutuhkan oleh masyarakat, terutama mereka yang sangat membutuhkan. Adapun empat aspek penting dalam komponen kesehatan finansial antara lain: permodalan (capital), kualitas aset (asset quality); rentabilitas (earning); dan likuiditas (liquidity). Sedangkan dalam mengukur tingkat kinerja
\end{abstract}


sosial, aspek yang dihitung antara lain: aspek Kontribusi Kepada Masyarakat (KKM), yaitu pembiayaan qardh, kinerja zakat, pelaksanaan fungsi sosial, dan pelaksanaan fungsi edukasi (CSR). Hasil penelitian menunjukkan bahwa secara keseluruhan dalam periode tahun 2002-2009, tingkat kesehatan finansial BSM lebih baik dari BMI. Sedangkan untuk tingkat kinerja sosial, dalam periode tahun 2003-2007 kinerja BSM lebih baik dari BMI.

Kata kunci: financial ratio, social ratio, time series, trend, correlation.

\begin{abstract}
Today, Islamic banks are expected to be a solution for global economic problems, whether for Muslims and non-Muslims (principle: rahmatan lil alamin). In order to achieve the desired goals, it is necessary to do the program in all lines of society, ranging from education in the field of education, business, and banking. By educating the community, the system and basic principles of sharia economy can be a mindset and a solid economic foundation. Furthermore, sharia banking is required to play an active role in socialization to the business world based on the principles of sharia and innovate against the needs of society and the development of the times so that its noble purpose can be accomplished. Islamic banks are developed as financial business institutions that conduct their business activities in line with the basic principles of Islamic economics. Islamic economic goals for sharia banks not only focus on commercial goals are reflected in the achievement of maximum profit alone, but also consider its role in providing welfare widely for the community. Contribution to participate in realizing the welfare of the community is the role of sharia banks in the implementation of social functions. Through this social function is expected to smooth the allocation and distribution of social funds needed by the community, especially those in great need. The four important aspects in the components of financial health, among others: capital, asset quality; profitability (earnings); and liquidity. Meanwhile, in measuring the level of social performance, the calculated aspect is among others: aspects of Community Contribution (KKM), ie qardh financing, zakat performance, implementation of social function, and implementation of
\end{abstract}


education function (CSR). The results show that overall in the period of 20022009, BSM financial health is better than BMI. As for the level of social performance, in the period 2003-2007 BSM performance is better than BMI.

Keyword: financial ratio, social ratio, time series, trend, correlation.

\section{A. Pendahuluan}

Bank-bank Islam yang didirikan di masa-masa awal, seperti The Farmers Credit Union di Pakistan pada akhir 1950 dan Mit Ghamer Savings Bank di Mesir tahun 1963 didirikan berdasarkan pada inisiatif sosial untuk mencapai tujuan sosial. Bahkan bank non-riba kedua yang didirikan di Mesir pada tahun 1972 diberi nama Nasser Social Bank. Suatu studi yang dilakukan Mashhour (1996) mengungkapkan bahwa aturan legislatif yang mendasari didirikannya bank Islam seperti Dubai Islamic Bank tahun 1975, Faisal Islamic Bank di Mesir dan Sudan tahun 1977, serta Jordan Islamic Bank tahun 1978 mensyaratkan bank tersebut untuk melakukan aktivitas sosial.

Triyuwono (2005) dalam makalahnya mengenai tingkat penilaian kesehatan bank syariah menyatakan bahwa kesehatan bank syariah antara lain dapat diukur dengan give out dan socio economic-wealth. Give out bermakna distribusi kesejahteraan yang telah berhasil diciptakan oleh bank syariah.
Kesejahteraan menurut perspektif syariah harus didistribusikan kepada direct participant, indirect participant dan alam. Sedangkan socio economic-wealth merupakan faktor "hasil" khususnya pada tingkat kesejahteraan materi.

\section{B. Perumusan Masalah}

Bank syariah dikembangkan sebagai lembaga bisnis keuangan yang melaksanakan kegiatan usahanya sejalan dengan prinsip-prinsip dasar dalam ekonomi Islam. Tujuan ekonomi Islam bagi bank syariah tidak hanya terfokus pada tujuan komersil yang tergambar pada pencapaian keuntungan maksimal semata, tetapi juga mempertimbangkan perannya dalam memberikan kesejahteraan secara luas bagi masyarakat.

Fungsi sosial yang paling nampak diantaranya: (i) penghimpunan dan penyaluran zakat, infaq, sadaqah, hibah dan waqaf (ZISW); (ii) mengeluarkan zakat dari keuntungan operasinya; (iii) memberikan pembiayaan kebajikan (qardh) agar terwujud distribusi ekonomi 
di masyarakat sehingga mereka menjadi lebih produktif.

Berdasarkan rumusan masalah diatas, penelitian ini akan mencoba menjawab beberapa pertanyaan penelitian sebagai berikut:

1. Bagaimana kinerja finansial BMI dan BSM?

2. Bagaimana kinerja sosial BMI dan BSM?

3. Bagaimana pengaruh rasio-rasio keuangan terhadap laba operasional BMI dan BSM?

4. Bagaimana hubungan antara laba operasional BMI dan BSM dengan Kontribusinya Kepada Masyarakat $(\mathrm{KKM})$ ?

\section{Metodologi Penelitian}

Penelitian ini merupakan penelitian deskriptif dan komparatif, serta studi kasus, yaitu menggambarkan sifat sesuatu yang sedang berlangsung pada saat riset dilakukan dan memeriksa sebab-sebab dari suatu gejala tertentu secara rinci mengenai suatu obyek tertentu selama kurun waktu tertentu dengan cukup mendalam dan menyeluruh (Husein Umar, 2003: 55-56).

Data penelitian yang digunakan dalam penelitian ini diambil dari Laporan Keuangan Tahunan dan Laporan Tahunan BMI dan BSM periode 2002-2009 yang telah dipublikasikan. Laporan Keuangan Tahunan yang digunakan adalah laporan keuangan yang telah diaudit, mencakup: Neraca, Laporan Laba Rugi, Laporan Investasi Terikat, Laporan Perubahan Modal, Arus Kas, Laporan Dana Zakat Infaq dan Shadaqah serta Catatan Atas Laporan Keuangan.

Untuk mengetahui perkembangan dan ramalan ke depan kinerja finansial maupun kinerja sosial digunakan Analysis Trend atas Time Series selama beberapa tahun terakhir, serta analisa korelasi dan regresi.

\section{TINJAUAN PUSTAKA}

\section{A. Sumber Permodalan Bank Syariah ${ }^{1}$}

Pengkategorian modal pinjaman sebagai salah satu sumber permodalan bank adalah konsensus yang dianut oleh perbankan konvensional. Dalam pandangan syariah, modal pinjaman (subordinated loan) itu termasuk dalam kategori qardh, yaitu pinjaman harta yang dapat diminta kembali. Dalam literatur fikih Salaf Ash Shalih, qard dikategorikan dalam akad tathawwu' atau akad saling membantu dan bukan transaksi komersial. Pemberi pinjaman tidak boleh minta imbalan atas pemberian pinjaman tersebut, karena setiap pemberian pinjaman yang disertai dengan permintaan imbalan termasuk kategori riba. Penerima pinjaman

\footnotetext{
${ }^{1}$ Arifin, Zainul, 2009. Dasar-Dasar Manajemen Bank Syariah. (cet.7). Jakarta: Azkia Publisher, hal. 161.
} 
wajib menjamin pengembalian pinjaman tersebut pada saat jatuh tempo. Oleh karena itu qardh mempunyai derajat preferensi yang tinggi, setara dengan kewajiban atau utang lainnya. Berdasarkan karakteristik tersebut, maka tidak beralasan bagi qardh untuk ikut menanggung resiko atau memberikan proteksi terhadap kegagalan atau kerugian bank ataupun memberikan proteksi terhadap kepentingan deposan. Dengan demikian pinjaman subordinasi tidak dapat dipertimbangkan untuk diperhitungkan sebagai modal bagi bank syariah.

Sumber utama modal bank syariah ${ }^{2}$ adalah: (a) modal inti (tier 1), (b) modal pelengkap (tier 2), dan (c) modal pelengkap tambahan (tier 3). Modal pelengkap (tier 2) dan modal pelengkap tambahan (tier 3) hanya dapat diperhitungkan setinggi-tingginya 100\% dari modal inti. Sedangkan modal inti (tier 1) dan modal pelengkap (tier 2) diperhitungkan dengan faktor pengurang yang berupa seluruh penyertaan yang dilakukan oleh bank.

Modal inti (core capital) adalah modal yang berasal dari para pemilik bank, yang terdiri dari modal disetor oleh para pemegang saham, cadangan dan laba ditahan. Sedangkan kuasi ekuitas adalah dana-dana yang tercatat dalam rekening-

\footnotetext{
${ }^{2}$ Ibid, hal. 164-165.
}

rekening bagi hasil (mudharabah). Modal inti inilah yang berfungsi sebagai penyangga dan penyerap kegagalan atau kerugian bank dan melindungi kepentingan para pemegang rekening titipan (wadiah) atau pinjaman (qardh), terutama atas aktiva yang didanai oleh modal sendiri dan dana-dana wadiah atau $\operatorname{qardh}^{3}$.

Sebenarnya dana-dana rekening bagi hasil (mudharabah) dapat juga dikategorikan sebagai modal, yang oleh karenanya disebut kuasi ekuitas. Namun demikian, rekening ini hanya dapat menanggung resiko atas aktiva yang dibiayai oleh dana dari rekening bagi hasil itu sendiri. Selain itu, pemilik rekening bagi-hasil dapat menolak untuk menanggung resiko atas aktiva yang dibiayainya, apabila terbukti bahwa resiko tersebut timbul akibat salah urus (mismanagement), kelalaian atau kecurangan yang dilakukan oleh manajemen bank selaku mudharib. Dengan demikian sumber dana ini tidak dapat sepenuhnya berperan dalam fungsi permodalan bank, namun demikian tetap merupakan unsur yang dapat diperhitungkan dalam pengukuran rasio kecukupan modal.

\footnotetext{
${ }^{3}$ Arifin, Zainul, 2009. Dasar-Dasar Manajemen Bank Syariah. (cet.7). Jakarta: Azkia Publisher, hal. 162.
} 


\section{B. Aplikasi Teori Assets-Liability Management Pada Bank Syariah ${ }^{4}$}

Perbedaan pokok perbankan konvensional dengan perbankan syariah terletak pada dominasi prinsip berbagi hasil dan berbagi risiko (profit and loss sharing) yang melandasi sistem operasionalnya. Hal ini antara lain tercermin pada beberapa karakteristik sebagai berikut:

1. Tidak sebagaimana bank konvensional, bank syariah hanya menjamin pembayaran kembali nilai nominal simpanan giro dan tabungan (seandainya mekanisme yang dipilih adalah wadiah), tetapi tidak menjamin pembayaran kembali nilai nominal dari deposito (investment deposit/ mudharabah depocit). Bank syariah juga tidak menjamin keuntungan atas deposito. Mekanisme pengaturan realisasi pembagian keuntungan final atas deposito pada bank syariah bergantung pada performance dari bank, tidak sebagaimana bank konvensional yang menjamin pembayaran keuntungan atas deposito berdasarkan tingkat bunga tertentu dengan mengabaikan performancenya.

2. Sistem operasional bank syariah

${ }^{4}$ Zainul Arifin, 2009. Dasar-Dasar Manajemen Bank Syariah. (cet.7). Jakarta: Azkia Publisher, hal. 155-157. berdasarkan pada system equity dimana setiap modal mengandung risiko. Oleh karena itu, hubungan kerjasama antara bank syariah dan nasabahnya adalah berdasarkan prinsip berbagi hasil dan berbagi risiko.

3. Dalam melakukan kegiatan pembiayaan, bank syariah menggunakan model pembiayaan muamalah maaliyah (Islamic modes of financing): PLS dan non-PLS. Sehubungan dengan itu, bank syariah melakukan pooling dana-dana nasabah dan berkewajiban menyediakan manajemen investasi yang profesional.

Berdasarkan karakteristik tersebut, risiko yang dihadapi oleh bank syariah lebih terfokus kepada risiko likuiditas serta risiko kredit dan tidak akan pernah mengalami risiko karena fluktuasi tingkat bunga. Likuiditas bank syariah banyak bergantung pada:

a. Tingkat kelabilan (volatility) dari simpanan (deposit) nasabah; kepercayaan pada dana-dana non PLS;

b. Kompetisi teknis yang berhubungan dengan pengaturan struktur liabilitas;

c. Ketersediaan asset yang siap dikonversikan menjadi kas;

d. Akses kepada pasar antar bank dan sumber dana lainnya, termasuk fasilitas lender of last resort dari bank sentral. Teknik duration gap management dapat diaplikasikan oleh bank syariah bukan 
dalam rangka menghindari risiko tingkat bunga, melainkan untuk mengatur cash flow atau mengendalikan likuiditasnya.

Di sisi lain, kualitas earning asset bank syariah akan bergantung pada beberapa hal:

1) Level, distribusi, dan tingkat kesulitan dari asset yang diklasifikasikan.

2) Level dan komposisi dari berkurangnya nilai asset.

3) Kecukupan dari cadangan penilaian kembali.

4) Bukti adanya kemampuan untuk mengadministrasikan dan memperoleh kembali kredit bermasalah.

\section{Masalah Pengelolaan Likuiditas Bank Syariah $^{5}$}

Salah satu kendala operasional yang dihadapi oleh perbankan Islam adalah kesulitan dalam mengendalikan likuiditasnya secara efisien. Hal itu terlihat pada beberapa gejala, antara lain:

1. Tidak tersedianya kesempatan investasi segera atas dana-dana yang diterimanya. Dana dana tersebut terakumulasi dan menganggur untuk

${ }^{5}$ Zainul Arifin, 2009. Dasar-Dasar Manajemen Bank Syariah. (cet.7). Jakarta: Azkia Publisher, hal. 155-157. beberapa hari sehingga mengurangi rata-rata pendapatan mereka

2. Kesulitan mencairkan dana investasi yang sedang berjalan, pada saat ada penarikan dana dalam situasi kritis. Akibatnya bank-bank Islam menahan alat likuidnya dalam jumlah yang lebih besar daripada rata-rata perbankan konvensional. Sekali lagi kondisi ini pun menyebabkan berkurangnya ratarata pendapatan bank. Penyimpan dana yang hanya mencari keuntungan lebih banyak cenderung memindahkan dananya ke bank lain, sementara bagi nasabah yang loyal terkesan bahwa mengikuti prinsip syariah berarti menambah beban.

Pada umumnya bank Islam mengalami dua macam kendala bila dibandingkan dengan bank konvensional, yaitu:

a. Kurangnya akses untuk memperoleh dana likuiditas dari bank sentral (kecuali hanya di beberapa negara Islam saja)

b. Kurangnya akses ke pasar uang (money market) sehingga bank Islam hanya dapat memelihara likuiditas dalam bentuk kas.

Untuk mengatasi masalah tersebut kebanyakan pengelola bank syariah masih harus memilih salah satu atau beberapa pilihan yang bersifat darurat, yaitu:

1) Menolak mengambil bunga 
2) Mengambil

bunga

dan menggunakannya untuk tujuan sosial berdasarkan fatwa

3) Menginvestasikannya pada emas dan/logam mulia lainnya secara tunai dan melakukan kontrak berjangka (forward contract)

4) Membiarkan diri kehilangan kesempatan di pasar uang dan menyimpan dananya di bank konvensional tanpa menerima bunga sebagai imbalan dari servis yang diperolehnya.

Aplikasi Corporate Social Responsibility (CSR) pada industri Perbankan Syariah $^{6}$

Aktivitas CSR perbankan syariah diselenggarakan sesuai dengan Undangundang No 21 Tahun 2008 yang mengatakan bank syariah dapat melakukan kegiatan yang bersifat bisnis, sosial yang bisa disalurkan kembali kepada orang yang berhak untuk menerimanya.

Pada tahun 2009 lalu, Perbankan Syariah di Indonesia bersinergi mencanangkan Islamic Banking Corporate Social Responsibility (IB-CSR) dengan total pembiayaan senilai $\mathrm{Rp} 1,450$ miliar.

IB CSR ini akan menyalurkan dananya kepada yang berhak dengan komposisi $50 \%$ untuk pengusaha ekonomi mikro lewat dana bergulir, 25\% untuk sektor

\footnotetext{
${ }^{6}$ Kajian Lisensi, Corporate Social Responsibility dalam Perspektif Islam, Rabu 19 Mei 2010.
}

pendidikan, dan $25 \%$ untuk bantuan bencana alam. Dari dana tersebut maka akan disisihkan 2,5\% untuk dana promosi.

\section{Menelisik Hubungan CSR dan GCG $(\text { Good Corporate governance })^{7}$}

Dalam keadaan persaingan ketat memperebutkan pasar demi mengejar keuntungan semaksimal mungkin, tentu mudah terjadi pelanggaran etika, yaitu pelanggaran asas-asas etika umum atau kaidah-kaidah dasar moral, diantaranya:

a) Asas kewajiban berbuat baik (beneficence, amar ma'ruf)

b) Asas kewajiban tidak berbuat yang menimbulkan madharat (nonmaleficence, do no harm, primum non nocere, nahi munkar)

c) Asas menghormati otonomi manusia (respect for person)

d) Asas berlaku adil (justice, fairness).

Setidaknya ada tiga alasan penting mengapa kalangan dunia usaha harus merespon dan mengembangkan isu tanggung jawab sosial sejalan dengan operasi usahanya.

Pertama, perusahaan adalah bagian dari masyarakat dan oleh karenanya wajar bila perusahaan memperhatikan

\footnotetext{
${ }^{7}$ Yusuf Wibisono, Membedah Konsep dan Aplikasi CSR, Fascho Publishing, 2007
} 
kepentingan masyarakat. Perusahaan harus menyadari bahwa mereka beroperasi dalam suatu tatanan lingkungan masyarakat. Kegiatan sosial ini berfungsi sebagai kompensasi atau upaya imbal balik atas penguasaan sumber daya alam dan sumber daya ekonomi oleh perusahaan yang kadang bersifat ekspansif dan eksploratif, di samping sebagai kompensasi sosial karena timbulnya ketidaknyamanan (discomfort) pada masyarakat.

Kedua, kalangan bisnis dan masyarakat sebaiknya memiliki hubungan yang bersifat simbiosa mutualisme. Untuk mendapatkan dukungan dari masyarakat, setidaknya licence to operate, wajar bila perusahaan juga dituntut untuk memberikan kontribusi positif kepada masyarakat, sehingga bisa tercipta harmonisasi hubungan bahkan pendongkrakan citra dan performa perusahaan.

Ketiga, kegiatan tanggung jawab sosial merupakan salah satu cara untuk meredam atau bahkan menghindari konflik sosial. Potensi konflik itu bisa berasal akibat dampak operasional perusahaan ataupun akibat kesenjangan struktural dan ekonomis yang timbul antara masyarakat dengan komponen perusahaan.

\section{HASIL dan PEMBAHASAN}

\section{A. Analisa Regresi:}

Fungsi Regresi 1: laba operasional $(\mathbf{Y})=$ $\mathbf{a}+\mathbf{b}$ (total pembiayaan)

Fungsi Regresi 2: laba operasional $(\mathbf{Y})=$ $\mathbf{a}+\mathbf{b}$ (rasio keuangan)

Fungsi Regresi 3: rasio kinerja sosial (Y) $=\mathbf{a}+\mathbf{b}$ (laba operasional)

\section{B. Hipotesis}

1. $\mathrm{H}_{0}$ : total pembiayaan $\mathrm{BSM}$ dan BMI tidak berpengaruh signifikan terhadap laba operasionalnya

$\mathrm{H}_{1}$ : total pembiayaan BSM dan BMI berpengaruh signifikan terhadap laba operasionalnya Terima $\mathrm{H}_{0}$ jika $\mathrm{r}_{\text {hit }}<\mathrm{r}_{\text {tabel }}$ Tolak $\mathrm{H}_{0}$ jika $\mathrm{r}_{\text {hit }} \geq \mathrm{r}_{\text {tabel }}$

2. $\mathrm{H}_{0}$ : rasio-rasio keuangan masing-masing bank tidak berpengaruh terhadap laba operasionalnya

$\mathrm{H}_{1}$ : rasio-rasio keuangan masingmasing bank berpengaruh terhadap laba operasionalnya

Terima $\mathrm{H}_{0}$ jika $\mathrm{r}_{\text {hit }}<\mathrm{r}_{\text {tabel }}$

Tolak $\mathrm{H}_{0}$ jika $\mathrm{r}_{\text {hit }} \geq \mathrm{r}_{\text {tabel }}$

3. $\mathrm{H}_{0}$ : laba operasional $\mathrm{BMI}$ dan $\mathrm{BSM}$ tidak berhubungan dengan kinerja sosialnya 
$\mathrm{H}_{1}$ : laba operasional BMI dan BSM berhubungan dengan kinerja sosialnya

Terima $\mathrm{H}_{0}$ jika $\mathrm{r}_{\text {hit }}<\mathrm{r}_{\text {tabel }}$

Tolak $\mathrm{H}_{0}$ jika $\mathrm{r}_{\text {hit }} \geq \mathrm{r}_{\text {tabel }}$

\section{Uji Korelasi dan Regresi (Analisa}

\section{Kesehatan Finansial)}

1. A. Total pembiayaan terhadap laba operasional BMI

Laba operasional berhubungan sangat kuat dengan total pembiayaan $(\mathrm{r}=0,990563, \mathrm{P}<$ 0,01) dengan persamaan regresi: $\mathbf{Y}$ $=\mathbf{- 3 5 , 9 7 8 9}+\mathbf{0 , 0 3 1 5 9 5} X$. Karena koefisien determinasi $\left(\mathrm{r}^{2}=\right.$ 0,98122), maka sebanyak 98\% laba operasional dipengaruhi oleh pembiayaan. Sisanya, yaitu $2 \%$ dijelaskan oleh hal-hal lain.

\section{B. Total pembiayaan terhadap}

\section{laba operasional BSM}

Laba operasional berhubungan sangat kuat dengan total pembiayaan $(\mathrm{r}=0,94548808, \mathrm{P}<$ 0,01) dengan persamaan regresi: $\mathbf{Y}$ $=$ 4781,92917+ 0,01875472 X. Karena koefisien determinasi $\left(\mathrm{r}^{2}=\right.$ 0,89395), maka sebanyak 89\% laba operasional dipengaruhi oleh pembiayaan. Sisanya, yaitu $11 \%$ dijelaskan oleh hal-hal lain.

Maka, total pembiayaan BMI dan BSM sangat mempengaruhi total laba operasional, korelasinya sangat kuat, berarti BMI dan BSM telah berfungsi dengan baik dalam membantu pihak-pihak yang membutuhkan dana.

\section{A. Total Dana Pihak ke-3} terhadap total pembiayaan BMI

Total Dana Pihak ke-3 berhubungan sangat kuat dengan total total pembiayaan $(\mathrm{r}=0,986633576, \mathrm{P}<$ 0,01) dengan persamaan regresi: $\mathbf{Y}=$ 432,1062497+ $0,900810586 \quad \mathrm{X}$. Karena koefisien determinasi $\left(\mathrm{r}^{2}=\right.$ 0,97), maka $97 \%$ yang mempengaruhi total pembiayaan adalah total dana pihak ke-3. Sisanya, yaitu 3\% dijelaskan oleh hal-hal lain.

\section{B. Total Dana Pihak ke-3 terhadap total pembiayaan BSM}

Total Dana Pihak ke-3 berhubungan sangat kuat dengan total total pembiayaan $(\mathrm{r}=0,998521643, \mathrm{P}<$ 0,01) dengan persamaan regresi: $\mathbf{Y}=$

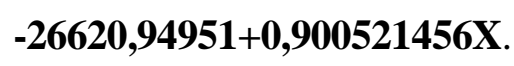

Karena koefisien determinasi $\left(\mathrm{r}^{2}=\right.$ 0,99), maka $99 \%$ yang mempengaruhi total pembiayaan adalah total dana pihak ke-3. Sisanya, yaitu $1 \%$ dijelaskan oleh 
hal-hal lain. Maka, baik BMI

maupun BSM sama-sama telah menjalankan fungsi intermediasi yang baik, hal ini ditandai oleh hubungan yang sangat kuat antara total pembiayaan dari dana pihak ketiga.

\section{A. NPF terhadap Laba}

\section{Operasional BMI}

NPF berhubungan lemah dengan laba operasional $(\mathrm{r}=0.205362, \mathrm{P}>$ 0,05) Karena koefisien determinasi $\left(\mathrm{r}^{2}=0,04\right)$, maka hanya $4 \%$ laba operasional yang dipengaruhi oleh NPF. Sisanya, yaitu 96\% dijelaskan oleh hal-hal lain.

\section{B. NPF terhadap Laba Operasional BSM}

NPF berhubungan lemah dengan laba operasional $(\mathrm{r}=0.325303202, \mathrm{P}$ $>0,05)$ Karena koefisien determinasi $\left(\mathrm{r}^{2}=0,11\right)$, maka hanya $11 \%$ dari NPF yang mempengaruhi laba operasional. Sisanya, yaitu $89 \%$ dijelaskan oleh hal-hal lain.

\section{A. ROA terhadap Laba}

\section{Operasional BMI}

ROA berhubungan kuat dengan laba operasional $(\mathrm{r}=0.805145327$, $\mathrm{P}<0,01)$, dengan persamaan regresi: $\quad Y=\mathbf{1 . 5 9 0 7 8 9 4 8 +}$ $\mathbf{0 . 0 0 3 4 5 7 7 8 7}$ X. Karena koefisien determinasi $\left(\mathrm{r}^{2}=0,65\right)$, maka sebesar $65 \%$ dari ROA yang berpengaruh terhadap laba operasional. Sisanya, yaitu $35 \%$ dijelaskan oleh hal-hal lain.

\section{B. ROA terhadap Laba \\ Operasional BSM}

ROA berhubungan lemah sekali dengan laba operasional $(\mathrm{r}=$ $0.1341605, \mathrm{P}>0,05)$. Karena koefisien determinasi $\left(\mathrm{r}^{2}=0,02\right)$, maka hanya sebesar $2 \%$ dari ROA yang berpengaruh terhadap laba operasional. Sisanya, yaitu $98 \%$ dijelaskan oleh hal-hal lain.

5. A. ROE terhadap Laba Operasional BMI

ROE berhubungan kuat sekali dengan laba operasional ( $\mathrm{r}=0.920591$, $\mathrm{P}<0,01)$, dengan persamaan regresi:

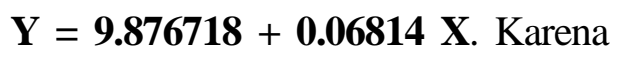
koefisien determinasi $\left(\mathrm{r}^{2}=0,84\right)$, maka sebesar $84 \%$ dari ROE yang berpengaruh terhadap laba operasional. Sisanya, yaitu $16 \%$ dijelaskan oleh hal-hal lain.

\section{B. ROE terhadap Laba}

\section{Operasional BSM}

ROE berhubungan lemah sekali dengan laba operasional $(\mathrm{r}=$ 0.0862104, $\mathrm{P}>0,05)$. Karena koefisien determinasi $\left(r^{2}=0,01\right)$, maka hanya sebesar $1 \%$ dari ROE 
yang berpengaruh terhadap laba operasional. Sisanya, yaitu 99\% dijelaskan oleh hal-hal lain.

6. A. CAR terhadap Laba Operasional BMI

CAR berhubungan negatif dengan laba operasional $(\mathrm{r}=-0.09599, \mathrm{P}>$ 0,05). Karena koefisien determinasi $\left(\mathrm{r}^{2}=0,01\right)$, maka hanya sebesar $1 \%$ dari CAR yang berpengaruh terhadap laba operasional. Sisanya, yaitu 99\% dijelaskan oleh hal-hal lain.

\section{B. CAR terhadap Laba \\ Operasional BSM}

CAR berhubungan negatif dengan laba operasional $(\mathrm{r}=-0.424998, \mathrm{P}$ $>$ 0,05). Karena koefisien determinasi $\left(\mathrm{r}^{2}=0,18\right)$, maka hanya sebesar $18 \%$ dari CAR yang berpengaruh terhadap laba operasional. Sisanya, yaitu $82 \%$ dijelaskan oleh hal-hal lain.
7. A. FDR terhadap Laba Operasional BMI

FDR berhubungan kuat sekali dengan laba operasional $(\mathrm{r}=$ 0.892075, $\mathrm{P}<0,01)$, dengan persamaan regresi: $\mathbf{Y}=\mathbf{7 6 . 9 0 4 1 3}+$ $\mathbf{0 . 0 8 3 7 0 3} \mathbf{X}$. Karena koefisien determinasi $\left(\mathrm{r}^{2}=0,80\right)$, maka sebesar $80 \%$ dari FDR yang berpengaruh terhadap laba operasional. Sisanya, yaitu $20 \%$ dijelaskan oleh hal-hal lain.

\section{B. FDR terhadap Laba \\ Operasional BSM}

FDR berhubungan positif dengan laba operasional $(\mathrm{r}=0.59814597, \mathrm{P}$ $<0,01)$, dengan persamaan regresi: $Y=81.3954497+4.1402 \mathrm{E}-05 \mathrm{X}$. Karena koefisien determinasi $\left(\mathrm{r}^{2}=\right.$ $0,36)$, maka hanya sebesar $36 \%$ dari FDR yang berpengaruh terhadap laba operasional. Sisanya, yaitu $64 \%$ dijelaskan oleh hal-hal lain.

\section{Rasio Tingkat Kesehatan Finansial dan Tren BMI dan BSM}

\section{Rasio Permodalan}

\section{CAR (Capital Adequacy Ratio) BMI}

\begin{tabular}{|lllllllll|}
\hline TAHUN & $\mathbf{2 0 0 2}$ & $\mathbf{2 0 0 3}$ & $\mathbf{2 0 0 4}$ & $\mathbf{2 0 0 5}$ & $\mathbf{2 0 0 6}$ & $\mathbf{2 0 0 7}$ & $\mathbf{2 0 0 8}$ & $\mathbf{2 0 0 9}$ \\
\hline RASIO & 10,55 & 13,04 & 12,17 & 16,33 & 14,23 & 10,69 & 10,83 & 11,1 \\
\hline \multirow{2}{*}{ TREN } & 13,68 & 13,35 & 12,70 & 12,37 & 12,04 & 11,71 & 11,39 & 11,06 \\
\hline
\end{tabular}


CAR (Capital Adequacy Ratio) BSM

\begin{tabular}{lllllllll}
\hline TAHUN & 2002 & 2003 & 2004 & 2005 & 2006 & 2007 & 2008 & 2009
\end{tabular}

$\begin{array}{lllllllll}\text { RASIO } & 39,29 & 20,87 & 10,57 & 11,88 & 12,56 & 12,44 & 12,66 & 13,22\end{array}$

$\begin{array}{lllllllll}\text { TREN } & 24,72 & 22,69 & 18,62 & 16,58 & 14,55 & 12,51 & 10,48 & 8,44\end{array}$

2. Rasio Kualitas Aset

NPF BMI

\begin{tabular}{|lcccccccc|}
\hline TAHUN & $\mathbf{2 0 0 2}$ & $\mathbf{2 0 0 3}$ & $\mathbf{2 0 0 4}$ & $\mathbf{2 0 0 5}$ & $\mathbf{2 0 0 6}$ & $\mathbf{2 0 0 7}$ & $\mathbf{2 0 0 8}$ & $\mathbf{2 0 0 9}$ \\
\hline RASIO & 3,43 & 2,12 & 2,19 & 2 & 4,84 & 1,33 & 3,85 & 4,1 \\
\hline TREN & 1,89 & 2,16 & 2,71 & 2,98 & 3,26 & 3,53 & 3,80 & 4,08 \\
\hline
\end{tabular}

NPF BSM

\begin{tabular}{lllllllll}
\hline TAHUN & 2002 & 2003 & 2004 & 2005 & 2006 & 2007 & 2008 & 2009
\end{tabular}

$\begin{array}{lllllllll}\text { RASIO } & 1,10 & 2,32 & 1,97 & 2,68 & 4,64 & 3,39 & 2,37 & 1,34\end{array}$

$\begin{array}{lllllllll}\text { TREN } & 1,56 & 1,79 & 2,25 & 2,48 & 2,71 & 2,94 & 3,16 & 3,39\end{array}$

\section{Rasio Rentabilitas}

ROA BMI

\begin{tabular}{|lcccccccc|}
\hline TAHUN & $\mathbf{2 0 0 2}$ & $\mathbf{2 0 0 3}$ & $\mathbf{2 0 0 4}$ & $\mathbf{2 0 0 5}$ & $\mathbf{2 0 0 6}$ & $\mathbf{2 0 0 7}$ & $\mathbf{2 0 0 8}$ & $\mathbf{2 0 0 9}$ \\
\hline RASIO & 2 & 1,33 & 1,80 & 2,53 & 2,10 & 2,27 & 2,60 & 0,45 \\
\hline TREN & 1,95 & 1,93 & 1,90 & 1,89 & 1,87 & 1,86 & 1,84 & 1,83 \\
\hline
\end{tabular}

ROA BSM

\begin{tabular}{lllllllll}
\hline TAHUN & 2002 & 2003 & 2004 & 2005 & 2006 & 2007 & 2008 & 2009
\end{tabular}

$\begin{array}{lllllllll}\text { RASIO } & 3,58 & 1,04 & 2,86 & 1,83 & 1,10 & 1,53 & 1,83 & 2,25\end{array}$

\begin{tabular}{lllllllll}
\hline TREN & 2,66 & 2,49 & 2,16 & 2 & 1,84 & 1,67 & 1,51 & 1,35
\end{tabular}

ROE BMI

\begin{tabular}{|lllllllll}
\hline TAHUN & 2002 & 2003 & 2004 & 2005 & 2006 & 2007 & 2008 & 2009
\end{tabular}

\begin{tabular}{lllllllll}
\hline RASIO & 17,23 & 8,81 & 15,49 & 18,1 & 21,99 & 23,24 & 33,14 & 8,03
\end{tabular}

$\begin{array}{lllllllll}\text { TREN } & 11,56 & 13,23 & 16,58 & 18,25 & 19,93 & 21,60 & 23,27 & 24,95\end{array}$ 
ROE BSM

\begin{tabular}{|lllllllll|}
\hline TAHUN & $\mathbf{2 0 0 2}$ & $\mathbf{2 0 0 3}$ & $\mathbf{2 0 0 4}$ & $\mathbf{2 0 0 5}$ & $\mathbf{2 0 0 6}$ & $\mathbf{2 0 0 7}$ & $\mathbf{2 0 0 8}$ & $\mathbf{2 0 0 9}$ \\
\hline RASIO & 7,40 & 3,61 & 22,28 & 23,39 & 18,27 & 32,22 & 21,34 & 40,00 \\
\hline TREN & 6,75 & 10,46 & 17,88 & 21,59 & 25,30 & 29,01 & 32,72 & 36,43 \\
\hline
\end{tabular}

\section{Rasio Likuiditas}

\section{FDR BMI}

\begin{tabular}{|lccccccll|}
\hline TAHUN & $\mathbf{2 0 0 2}$ & $\mathbf{2 0 0 3}$ & $\mathbf{2 0 0 4}$ & $\mathbf{2 0 0 5}$ & $\mathbf{2 0 0 6}$ & $\mathbf{2 0 0 7}$ & $\mathbf{2 0 0 8}$ & $\mathbf{2 0 0 9}$ \\
\hline RASIO & 84 & 76,97 & 86,03 & 89,08 & 83,60 & 99,16 & 104,41 & 85,82 \\
\hline TREN & 79,28 & 81,61 & 86,27 & 88,59 & 90,92 & 93,25 & 95,58 & 97,9 \\
\hline
\end{tabular}

\section{FDR BSM}

\begin{tabular}{|lllllllll|}
\hline TAHUN & $\mathbf{2 0 0 2}$ & $\mathbf{2 0 0 3}$ & $\mathbf{2 0 0 4}$ & $\mathbf{2 0 0 5}$ & $\mathbf{2 0 0 6}$ & $\mathbf{2 0 0 7}$ & $\mathbf{2 0 0 8}$ & $\mathbf{2 0 0 9}$ \\
\hline RASIO & 74,55 & 82,57 & 92,50 & 83,09 & 90,21 & 92,96 & 89,12 & 87,96 \\
& & & & & & & \\
\hline TREN & 80,35 & 81,76 & 84,59 & 86,01 & 87,42 & 88,84 & 90,26 & 91,67 \\
\hline
\end{tabular}

E. Uji Korelasi Laba Operasional BMI dan BSM terhadap Kontribusi Kepada Masyarakat (KKM)Analisa Kinerja Sosial

1. Kontribusi Pembiayaan Qardh (QR)

\section{a. BMI}

Laba operasional berhubungan positif dengan Kontribusi Pembiayaan Qardh ( $\mathrm{r}=$ 0,649896, $\mathrm{P}>$ 0,05). Karena koefisien determinasi $\left(\mathrm{r}^{2}=\right.$ 0,42 , maka hanya $42 \%$ dari laba operasional yang mempengaruhi kontribusi pembiayaan qardh. Sisanya, yaitu sebanyak $58 \%$ dijelaskan oleh hal-hal lain.

\section{b. BSM}

Laba operasional berkorelasi negativeltidak berhubungan dengan Kontribusi Pembiayaan Qardh $(\mathrm{r}=-0,406827227, \mathrm{P}$ > 0,05) Karena koefisien determinasi $\left(\mathrm{r}^{2}=0,1655\right)$, maka hanya $16,5 \%$ dari laba operasional yang mempengaruhi kontribusi pembiayaan qardh. Sisanya, 
yaitu sebanyak $83,5 \%$

dijelaskan oleh hal-hal lain.

Maka, laba operasional baik BMI maupun BSM belum dapat berperan maksimal dalam kontribusi pembiayaan qardh, akan tetapi BMI masih lebih baik dalam kontribusinya selama ini dibandingkan BSM.

\section{Kinerja Zakat (ZR)}

\section{a. BMI}

Laba operasional berhubungan sangat kuat dengan Kinerja Zakat $(\mathrm{r}=0,980768, \mathrm{P}<0,01)$ Karena koefisien determinasi $\left(\mathrm{r}^{2}=0,9619\right)$, maka sebanyak 96\% dari laba operasional yang mempengaruhi Kinerja Zakat. Semakin tinggi laba, maka semakin besar zakat yang ditunaikan oleh BMI. Sisanya, yaitu sebanyak $4 \%$ dijelaskan oleh hal-hal lain.

b. BSM

Laba operasional tidak berhubungan dengan Kinerja Zakat $(\mathrm{r}=0,025486913, \mathrm{P}$ > $0,05)$.

Maka, BMI lebih komitmen untuk menunaikan dana zakatnya daripada BSM, karena korelasi laba operasional BMI sangat kuat terhadap kinerja zakatnya, sedangkan rasio zakat BSM tidak berhubungan linear dengan tingkat laba operasionalnya.

\section{Pelaksanaan Fungsi Sosial (RFS)}

\section{a. BMI}

Laba operasional berhubungan positif dengan Pelaksanaan Fungsi Sosial ( $r=0,649896$, $\mathrm{P}$ $>$ 0,05 ) Karena koefisien determinasi $\left(r^{2}=0,42\right)$, maka hanya sebanyak $42 \%$ dari laba operasional yang mempengaruhi Pelaksanaan Fungsi Sosial. Sisanya, yaitu sebanyak 58\% dijelaskan oleh hal-hal lain.

\section{b. BSM}

Laba operasional berkorelasi negative dan berhubungan lemah dengan Pelaksanaan Fungsi Sosial $(\mathrm{r}=$ $0,410659381, \quad \mathrm{P}>0,05$ ) Karena koefisien determinasi $\left(\mathrm{r}^{2}=0,16864\right)$, maka hanya sebanyak $17 \%$ dari laba operasional yang mempengaruhi Pelaksanaan Fungsi Sosial. Sisanya, yaitu sebanyak $83 \%$ dijelaskan oleh hal-hal lain. 
Maka, BSM memiliki korelasi

negatif dalam pelaksanaan

fungsi sosialnya, sedangkan

BMI masih ada korelasinya

walaupun lemah.

\section{Pelaksanaan Fungsi Edukasi} (CSR)

\section{a. BMI}

Laba operasional berhubungan lemah sekali dengan Pelaksanaan Fungsi Edukasi (r $=0,053341, \mathrm{P}>0,05)$.

\section{b. BSM}

Laba operasional berkorelasi negatif/tidak berhubungan sama sekali dengan Pelaksanaan Fungsi Edukasi (r $=-0,271899842, \mathrm{P}>0,05)$.

Maka, BSM memiliki korelasi negatif dalam pelaksanaan fungsi edukasinya, sedangkan BMI masih ada korelasinya walaupun sangat lemah.

\section{F. Rasio Peringkat Kinerja Sosial BMI} dan BSM-Kontribusi Kepada
Masyarakat (KKM)

\section{Rasio Pembiayaan Qardh (QR)}

Melalui hasil penghitungan Rasio Pembiayaan Qardh atau Qardh Ratio (QR) dapat diketahui besarnya kontribusi pembiayan qardh BMI dan BSM bagi masyarakat. Semakin tinggi komponen ini akan mengindikasikan kepedulian BMI dan BSM yang tinggi kepada pihak yang mengalami kesulitan. QR dihitung dengan membandingkan pembiayaan qardh dengan total pembiayaan yang dilakukan oleh bank tersebut.

Kepedulian BSM terhadap pihak lain atau nasabah yang mengalami kesulitan lebih baik dari BMI, dilihat dari rasio QR. Nilai rata- rata $\mathrm{QR}$ BSM pada periode tahun 2003-2007 adalah sebesar $3,23 \%$ lebih tinggi 2,73\% dari nilai rata-rata $\mathrm{QR}$ BMI yang hanya $0,51 \%$. Nilai QR BSM tertinggi adalah sebesar 5,61\% terjadi pada tahun 2003 dan terendah sebesar 1,06\% terjadi pada tahun 2004. Sedangkan nilai QR BMI terendah sebesar $0,06 \%$ terjadi pada tahun 2003 dan tertinggi sebesar $1,42 \%$ pada tahun 2007.

Maka dengan demikian tahun 2003 dan 2007, QR BSM berada pada peringkat pertama, sedangkan untuk tahun 2004 dan 2005 berada pada peringkat keempat, serta tahun 2006 berada pada peringkat kedua. Sedangkan 
QR BMI tahun 2003, 2004, 2005

dan 2006 berada pada peringkat kelima, sedangkan tahun 2007 mengalami perbaikan menjadi peringkat keempat.

\section{Rasio Kinerja Zakat (ZR)}

Rasio kinerja zakat atau zakah ratio (ZR) digunakan dalam penelitian ini untuk mengukur besarnya kontribusi zakat perusahaan yang dikeluarkan oleh BMI dan BSM.

Zakat tersebut kemudian akan dapat dinikmati oleh mustahiq zakat, yang merepresentasi kelompok yang membutuhkan dalam masyarakat. ZR diperoleh dengan membandingkan zakat yang dibayarkan BMI dan BSM dengan laba sebelum pajak. Semakin tinggi komponen ini akan mengindikasikan zakah performance masing-masing bank syariah tersebut.

Dari nilai rata-rata ZR pada periode tahun 2003-2007 menunjukkan bahwa BMI memberikan kontribusi zakat perusahaan yang lebih besar. Nilai rata-rata ZR BMI pada periode tersebut adalah sebesar 1,73\%, lebih tinggi $0,67 \%$ dari nilai rata- rata ZR BSM yang mencapai 1,06\%. Nilai ZR BMI tertinggi adalah sebesar $3,18 \%$ terjadi pada tahun 2007 dan terendah sebesar 0,00\% terjadi pada tahun 2003. Sedangkan nilai ZR BSM terendah sebesar juga $0,00 \%$ terjadi pada tahun 2003 dan tertinggi sebesar 2,19\% pada tahun 2006.

Dari hasil perhitungan menunjukkan bahwa nilai ZR BMI tahun 2003 berada pada peringkat lima, tahun 2004 peringkat empat, tahun 2005 berada pada peringkat tiga, tahun 2006 pada peringkat dua, dan tahun 2007 meningkat menjadi peringkat satu. Sedangkan nilai ZR BSM pada tahun 2003 dan 2004 berada pada peringkat lima, tahun 2005 mendapat peringkat tiga, tahun 2006 peringkat dua, dan tahun 2007 memburuk menjadi peringkat lima.

\section{Rasio Pelaksanaan Fungsi Sosial} (RFS)

Melalui hasil perhitungan Rasio Pelaksanaan Fungsi Sosial (RFS) dapat diukur manfaat yang diberikan oleh BMI dan BSM bagai masyarakat secara total dari zakat dan pembiayan kebajikan (qard). Nilai RFS didapatkan dengan membandingkan 
pembiayan qardh ditambahkan dengan pembayaran zakat perusahaan dengan modal inti atau total ekuitas. Menurut BI (2007), semakin tinggi komponen ini mengindikasikan pelaksanaan fungsi sosial bank syariah semakin tinggi.

Dari data menunjukkan bahwa pelaksanaan fungsi sosial BSM melalui zakat dan pembiayaan qardh lebih baik dari BMI, dilihat dari rasio RFS. Nilai rata-rata rasio RFS BSM pada periode tahun 2003-2007 adalah sebesar 29,66\% lebih tinggi $24,31 \%$ dari nilai rata-rata RFS BMI yang hanya 5,35\%. Nilai RFS BSM tertinggi adalah sebesar $64,58 \%$ terjadi pada tahun 2007 dan terendah sebesar 10,30\% terjadi pada tahun 2004. Sedangkan nilai RFS BMI terendah sebesar 0,46\% terjadi pada tahun 2003 dan tertinggi sebesar $15,22 \%$ pada tahun 2007.

Maka dengan demikian tahun 2003, 2006 dan 2007, RFS BSM berada pada peringkat satu, sedangkan untuk tahun 2004 dan 2005 berada pada peringkat tiga. Sedangkan RFS BMI tahun 2003, 2004, 2005 dan 2006 berada pada peringkat lima, sedangkan tahun
2007 mengalami perbaikan signifikan menjadi peringkat dua.

\section{Rasio Pelaksanaan Fungsi} Edukasi (CSR)

\section{Corporate}

Social

Responsibility (CSR) merujuk pada semua hubungan yang terjadi antara perusahaan dengan semua stakeholders, termasuk pelanggan, pegawai, komunitas, pemilik, pemerintah, supplier bahkan kompetitor. CSR merupakan konsep di mana BSM dan BMI secara sukarela menyumbangkan sesuatu ke arah masyarakat yang lebih baik dan lingkungan hidup yang lebih bersih. Kegiatankegiatan yang dijalankan BSM dan BMI di tahun 2009 terus diupayakan agar sesuai dengan konsep dasar CSR, yaitu membantu mengatasi atau mengurangi permasalahan yang terjadi di masyarakat, mengusahakan terjadinya perubahan perilaku masyarakat, dan mengupayakan pencapaian kesejahteraan kehidupan masyarakat.

Rasio pelaksanaan fungsi edukasi dalam penelitian ini digunakan untuk mengukur besarnya fungsi corporate social 
reponsibility (CSR) dalam proses pembelajaran masyarakat yang telah dijalankan BMI dan BSM. Rasio CSR dihitung dengan membandingkan biaya edukasi publik dengan total biaya operasional. Biaya edukasi publik dicerminkan oleh biaya promosi. Sebagaimana menurut BI (2007), semakin tinggi rasio CSR ini menunjukkan semakin besar peran bank syariah tersebut dalam proses pembelajaran masyarakat.

Dari nilai rata-rata rasio CSR pada periode tahun 20032007 menunjukkan bahwa BMI memberikan kontribusi edukasi publik yang lebih besar. Nilai ratarata rasio CSR BMI pada periode tersebut adalah sebesar 7,06\%, lebih tinggi 2,69\% dari nilai ratarata rasio CSR BSM yang mencapai $4,37 \%$. Nilai rasio CSR BMI tertinggi adalah sebesar $7,33 \%$ terjadi pada tahun 2004 dan terendah sebesar $6,79 \%$ terjadi pada tahun 2007. Sedangkan nilai rasio CSR BSM terendah sebesar 2,46\% terjadi pada tahun 2006 dan tertinggi sebesar $6,17 \%$ pada tahun 2003. Secara keseluruhan rasio kontribusi edukasi publik BMI pada setiap tahun lebih baik dari BSM.
Dari hasil perhitungan diatas menunjukkan bahwa nilai rasio CSR BMI tahun 2003 dan 2007 berada pada peringkat dua, sedangkan tahun 2004, 2005 dan 2006 pada peringkat satu. Sedangkan nilai rasio CSR BSM pada tahun 2003 dan 2004 berada pada peringkat dua, tahun 2005 dan 2007 peringkat tiga, dan tahun 2006 mendapat peringkat empat.

\section{PENUTUP}

\section{A. Kesimpulan}

Hasil penelitian menunjukkan bahwa secara keseluruhan dalam periode tahun 2002-2009, kesehatan finansial BSM lebih baik dari BMI. Dari hasil perbandingan antar rasio keuangan, BSM masih lebih baik dalam rasio permodalan (CAR) sebanyak 16,69\%, sedangkan CAR BMI 12,37\%, begitupun dalam hal kualitas asset, NPF BSM lebih baik sedikit, yaitu $2,48 \%$ dibandingkan NPF BMI yang mencapai $2,98 \%$, dalam hal rentabilitas secara rata-rata BSM juga masih unggul dari BMI, yaitu sebesar 11,8\%, sedangkan BMI yang mencapai $10,1 \%$ atau hanya berbeda $1,7 \%$ saja, dan yang terakhir adalah rasio likuiditas yang ditunjukkan oleh nilai FDR, yang menunjukkan bahwa rasio FDR BMI lebih baik dibandingkan BSM, yaitu $88,63 \%$ berbanding $86 \%$. Jadi, 
secara kumulatif tingkat kesehatan finansial yang ditunjukkan oleh rasio keuangan menyimpulkan bahwa BSM masih lebih baik dari BMI untuk periode 2003-2009.

Sedangkan untuk tingkat kinerja sosial, dalam periode tahun 2003-2007 kinerja BSM lebih baik dari BMI. Secara rata-rata dalam periode tersebut tingkat kinerja sosial BSM yaitu Kontribusi Kepada Masyarakat (KKM) mendapatkan nilai akhir sebesar 13,00, sedangkan nilai komposit dari KKM BMI hanya sebesar 10,40 .

Dari sini dapat dilihat bahwa BSM memiliki aspek KKM yang lebih baik dari BMI. Berdasarkan masing-masing tahun, penelitian ini juga menemukan bahwa nilai kinerja sosial BMI lebih baik dari BSM hanya terjadi pada tahun 2004. Selebihnya semenjak tahun 2003, 2005 sampai dengan tahun 2007 kinerja sosial BSM lebih baik dibandingkan dengan BMI. Meski demikian trend kinerja sosial BMI terus meningkat, dan selisih skornya dengan kinerja sosial BSM juga semakin kecil.

Berdasarkan hasil penelitian, diketahui bahwa: pertama, total pembiayaan pada kedua bank memiliki hubungan yang sangat kuat dan signifikan terhadap laba operasionalnya, kedua, dana pihak ketiga juga menyumbang mayoritas bagi laba operasional baik BMI maupun BSM. Hal itu menunjukkan bahwa BMI dan BSM telah menunjukkan kualitas dan integritasnya yang berperan banyak dalam fungsi intermediasi perbankan, serta pembiayaan lebih difokuskan pada sector riil, terutama bidang UMKM yang lebih membantu para pegusaha mikro, kecil, dan menengah. Ketiga, NPF berhubungan lemah dengan dana pihak ketiga bagi kedua bank tersebut. Hal ini berarti para deposan tidak terlalu merisaukan tingkat NPF yang tinggi di kedua bank tersebut. Keempat, NPF juga tidak berhubungan kuat dengan laba operasional masingmasing bank, berarti laba operasional tidak banyak terpengaruh oleh tingkat NPF yang cukup tinggi. Kelima, ROA pada BMI berhubungan cukup kuat terhadap laba operasionalnya, sedangkan tidak dengan BSM. Keenam, ROE pada BMI berhubungan cukup kuat terhadap laba operasionalnya, sedangkan terhadap BSM tidak demikian. Ketujuh, CAR pada kedua bank ini berhubungan negative dengan laba operasionalnya, berarti tingkat CAR tidak mempengaruhi secara signifikan pada laba operasionalnya. Kedelapan, FDR terhadap laba operasional BMI berkorelasi positif dan signifikan, sedangkan FDR terhadap laba operasional BSM berkorelasi positif, tetapi tidak signifikan.

Kemudian, pada uji korelasi dan regresi yang mengukur tingkat laba operasional terhadap rasio Kontribusi 
Kepada Masyarakat (KKM), antara lain: pertama, laba operasional terhadap kontribusi pembiayaan qardh BMI berhubungan positif, tetapi tidak signifikan, sedangkan pada BSM tidak berhubungan positif. Kedua, laba operasional terhadap Rasio zakat BMI berhubungan positif dan sangat kuat, sebaliknya laba operasional BSM berhubungan positif, tetapi sangat lemah. Ketiga, Pelaksanaan fungsi sosial pada BMI berkorelasi positif dengan laba operasional, sedangkan BSM berkorelasi negatif dan tidak signifikan hubungannya. Keempat, laba operasional BMI berhubungan positf, namun sangat lemah sekali terhadap fungsi CSR nya (edukasi dalam hal ini), sedangkan rasio fungsi edukasi BSM malah berkorelasi negatif dengan laba operasionalnya.

Berikutnya, terlihat bahwa masingmasing rasio keuangan antara BMI dan BSM tidak berbeda nyata, atau setara. Artinya, kedua bank tersebut memiliki rasio keuangan yang hampir sama nilainya atau sedikit perbedaannya, sehingga masih cukup berimbang tingkat kesehatan finansialnya.

\section{B. Rekomendasi}

Dari penelitian ini, peneliti memberikan rekomendasi atau saran sebagai berikut:

Pertama, untuk mempertahankan atau meningkatkan kinerja bisnis, baik bagi BMI maupun BSM, aspek penting yang dominan dan perlu diperhatikan adalah kualitas aktiva produktif (KAP) dan pembiayaan non-performing (NPF). Terlebih dalam kondisi makro ekonomi yang berat yang akan dihadapi bank syariah pada tahun-tahun berikutnya. Menjaga dan memperbaiki KAP dan NPF menjadi hal mutlak, karena dari sinilah kondisi pendapatan utama bank akan terbentuk, yang berikutnya akan menentukan pada tingkat profitabilitasnya. Selain itu pihak bank juga harus meningkatkan permodalan internal, dengan cara meningkatkan profit, meningkatkan laba ditahan, dan memperbanyak cadangan-cadangan modal lainnya, serta dapat juga dengan meningkatkan permodalan eksternal yaitu melakukan pinjaman antar bank, rights issue (penawaran saham terbatas), dan menerbitkan obligasi syariah. Disamping itu, likuiditas harus tetap terjaga, hal ini juga penting sebagai tindak lanjut bagi bank dalam memaksimalkan tingkat FDR nya berupa pembiayaan yang pada akhirnya akan menentukan sekali tingkat keuntungan bank. Kedua, secara umum, kedua bank syariah tersebut perlu meningkatkan kinerja sosialnya. Kontribusi sosial BMI dan BSM perlu diperhatikan. Hal ini penting mengingat kehadiran bank syariah diharapkan dapat 
mendorong Kontribusi Kepada Masyarakat (KKM) baik dalam bentuk Pembiayaan qardh, pemaksimalan zakat, serta pelaksanaan fungsi edukasi (CSR). Dan ketiga, dalam penelitian ini tentunya masih banyak kekurangan, baik akibat keterbatasan waktu, sumber data dan juga berbagai keterbatasan dari peneliti. Untuk itu diperlukan penelitian lanjutan dari peneliti-peneliti berikutnya, terutama untuk mengelaborasi kinerja sosial bagi bank syariah tersebut. Penelitian tersebut diantaranya dapat memperdalam hasil penelitian ini baik dengan menguji komponen aspek lain seperti Kontribusi Pembangunan Ekonomi (KPE), Kontribusi Untuk Stakeholder (KUS), Peningkatan Kapasitas SDI dan Riset (PKSR) serta Distribusi Pembangunan Ekonomi (DPE) yang dinilai dalam kinerja sosial bank syariah, penentuan nilai dan juga model pembobotannya. Dengan demikian diharapkan kedepan akan terbentuk satu model standar untuk mengukur kinerja sosial bank syariah yang solid, valid dan reliabel yang kemudian dapat ditetapkan dan digunakan oleh pihak regulator, dalam hal ini Bank Indonesia, serta bagi industri perbankan syariah secara keseluruhan dan juga bagi Lembaga Keuangan Syariah, baik bank dan non-bank.

\section{DAFTAR PUSTAKA}

Antonio, Muhammad Syafi'i, 2001. Bank Syariah dari Teori ke Praktik. Jakarta: Gema Insani Press.

1999. Bank Syariah; Wacana Ulama \& Cendekiawan. Jakarta: Bank Indonesia \& Tazkia Institute.

Arifin, Zainul, 2009. Dasar-Dasar Manajemen Bank Syariah. (cet.7). Jakarta: Azkia Publisher.

Capra, M. Umer \& Ahmed, Habib, 2002. Corporate Governance in Islamic Financial Institution Jedah: IRTIIDB.

Capra, M. Umer, 2002. Pengharaman Bun ga Bank; Rasionalkah ?Analisis Sy ar'i dan Ekonomi dibalik Penghar aman Bunga Bank. Jakarta: SEBI.

Dewan Syariah Nasional Majelis Ulama Indonesia (DSN-MUI), 2006. Himpunan Fatwa Dewan Syariah Nasional. Jakarta: DSN MUI dan BI.

Hatler, Gerald .O, 1991. Bank Investment and Fund Management, (Washington DC: American Bankers Association).

Hendro, 2010. Kewirausahaan SMK (Jl.3). Jakarta: PT. Penerbit Erlangga.

Idrus, Muhammad, 2009. Metode Penelitian Ilmu Sosial (ed. II). 
Jakarta: PT. Penerbit Erlangga.

Ifham Sholihin, Ahmad, 2010. Kamus

Pintar Ekonomi Syariah. Jakarta:

Penerbit PT. Gramedia Pustaka

Utama.

Iskandar, 2008. Metodologi Penelitian

Pendidikan dan Sosial (Kuantitatif

dan Kualitatif). Jakarta: Gaung

Persada Press.

Kuncoro, Mudrajad, 2009. Metode Riset untuk Bisnis dan Ekonomi (ed. III).

Jakarta: PT. Penerbit Erlangga.

Lewis, Mervin K. \& Algaoud, Latifa M., 2007. Perbankan Syariah; P rinsip, Praktik dan Prospek. Edis i terjemah. Jakarta: Serambi.

Machmud, Amir \& Rukmana, 2010. Bank Syariah (Teori, Kebijakan, dan Studi Empiris di Indonesia). Jakarta: PT. Penerbit Erlangga.

Murray R. Spiegel, Larry J. Stephens, 2007, Schaum's Outlines, Statistik ed. III (terjemahan), Penerbit Erlangga.

Rivai, Veithzal \& Permata Veithzal, Rivai. 2008. Islamic Financial Management. Jakarta: PT. Raja Grafindo Persada.

Santosa, Purbayu Budi \& Hamdani, Muliawan, 2007. Statistik Deskriptif dalam Bidang Ekonomi dan Niaga. Jakarta: PT. Penerbit Erlangga.
Siamat, Dahlan, 2005. Manajemen Lembaga Keuangan; Kebijakan Moneter dan Perbankan (ed.V). Jakarta: Lembaga Penerbit Fakultas Ekonomi Universitas Indonesia.

Silvanita, Ktut, 2009. Bank \& Lembaga Keuangan Lain. Jakarta: PT. Penerbit Erlangga.

Taswan, 2010. Manajemen Perbankan; Konsep, Teknik, dan Aplikasi. UPP STIM YKPN Yogyakarta.

Wibisono, Yusuf, 2007. Membedah Konsep \& Aplikasi CSR. Gresik: Fascho Publishing.

\section{Makalah:}

Abdul Karim, Rifaat Ahmad, "The Impact of The Basle Capital Adequacy Ratio Regulation on the Financial Strategy of Islamic Banks" dalam Proceedings of the $9^{\text {th }}$ Expert Level Conference on Islamic Banking, disponsori oleh Bank Indonesia dan International Association of Islamic Banks, 7-8 April 1995, Jakarta.

Kajian Lisensi, Corporate Social Responsibility dalam Perspektif Islam, Rabu 19 Mei 2010, Jakarta.

Meutia, Inten, Syariah Enterprise Theory Sebagai Teori Dasar Pengungkapan Tanggung Jawab Sosial Bank Islam. Makalah Call For Paper International Seminar 
and Symposium on Implementation of Islamic Economics To Positive Economics in The World as Alternative of Conventional Economics System: Toward Development in The New Era of The Holistic Economics Unair, 1-2 Agustus 2008.

Setiawan, Azis Budi. 2009. Analisis Kesehatan Finansial dan Kinerja Sosial Bank Umum Syariah di Indonesia. Makalah disampaikan pada "National Seminar on Islamic Banking Research", Kerjasama Magister Bisnis Keuangan Islam Universitas Paramadina, Ikatan Ahli Ekonomi Islam (IAEI) dan Masyarakat Ekonomi Syariah (MES), Auditorium Nurcholis Madjid, Jakarta, Kamis, 30 Juli 2009.

\section{Publikasi lainnya:}

Bank Indonesia, 2007. PBI No.9 Tahun 2007 tentang Sistem Penilaian
Tingkat Kesehatan Bank Umum Berdasarkan Prinsip Syariah. 2005. PBI No.7 Tahun 2005 tentang Akad Penghimpunan dan Penyaluran Dana Bagi Bank yang Melaksanakan Kegiatan Usaha Berdasarkan Prinsip Syariah. , 2003. PBI No. 5: Tahun 2003 tentang Penyisihan Penghapusan Aktiva Produktif Bagi Bank Syariah. , 2007. Kodifikasi Produk

Perbankan Syariah, Jakarta: Direktorat Perbankan Syariah Bank Indonesia.

Bank Muamalat Indonesia, Laporan Akhir Tahun 2002-2009. Jakarta: PT. BMI.

Bank Syariah Mandiri, Laporan Akhir Tahun 2002-2009. Jakarta: PT. BSM.

UU No. 21 Tahun 2008 Tentang Perbankan Syariah. 